\title{
Use of Android Media in Indonesian Language Skills Learning
}

\author{
Suhartono $^{1}$ \\ ${ }^{1}$ The Faculty of Teacher Training and Education, Sebelas Maret University, Surakarta, Indonesia \\ Email: suhartono@fkip.uns.ac.id
}

\begin{abstract}
The purposes of this study are to describe the use of android media in learning and to improve the quality of learning Indonesian language skills of student teachers of primary education through the use of android media. The research method of the study uses action research design. The subjects of this study are the student teachers of primary education department Universitas Sebelas Maret in Kebumen.This study uses subjective tests, interviews, and observations as techniques of collecting data. The observation data were generated by collecting the data during the learning process to find out how the activities of the students in using the mobile phone through their activities in social media (Facebook) and WhatsApp group. Furthermore, the subjective tests were collected in written assessment in a form of essay composition and oral assessment in a form of speaking performance. Data analysis used is qualitative analysis, consisting (1) data reduction, (2) display / presentation of data, and (3) conclusion / verification. The conclusion of the research shows that (1) Knowledge sharing between students and lecturers is effective through listening and speaking activities; (2) Reading activities conducted with the help of android smartphone media can increase the knowledge of students in various fields so that support the skills of speaking and writing. (3) Eventually, students of student teachers of primary education are able to produce comprehensive writing in the form of responses, essays, and book reviews.
\end{abstract}

Keywords: android; media; language skills

\section{INTRODUCTION}

The development of science and technology are so rapidly that encourages every human to respond to all these developments quickly in order to follow. Human resources who have the ability to respond to the development of science and technology are needed in education. The ability to understand the development of science and technology requires critical, systematic, logical, and creative thinking and also willingness to cooperate effectively.

The world of education cannot be separated from the learning process including teachers, students, and learning environments that affect each other in order to achieve the objectives of learning. Media is one of the factors supporting the achievement of learning objectives. This is related to the appropriate and varied use of media in the learning process which can improve learning motivation and reduce the passive attitude of students [5]. 
The development of mobile technology is currently so rapid, one of the mobile devices that are now commonly used are mobile phones. Almost all students have cellphones; some even have more than one cell phone. The more students own and use the mobile device, the greater the opportunity to use technology tools in education. Learning that utilizes mobile phone technology is called mobile learning (M-Learning). Mobile learning is one of the alternative developments of learning media. The presence of mobile learning is intended to be a complement to learn and provide an opportunity for students to learn less mastered material anywhere and anytime [17]

Utilization of media in the form of cellular phone in PGSD FKIP UNS is not yet optimal. There still many students who are using laptops or even some are using books in lecturing activity. By using a laptop as a medium of learning will make it difficult for students to bring the device because of the heavy and bothering. There still lecturers who are using conventional methods in teaching and less skilled using laptop.

The existence of cell phones, especially android, is actually very useful in learning. Seeing this potential, the use of learning media using android mobile phone is the appropriate alternative. This is based on the fact that Android operating system transformed into a system that is most widely used on smartphones. In addition to be more practical and simple, many Android smartphones are affordable with a price range of 1 million rupiah.

In 2011 there were 835 million smartphone users in the world and 5.6 billion other mobile phone lower technology users, or feature phones. The phone as a whole is one of the most successful technologies in the last two decades. Along with the rapid development of this technology, more and more educators are using this technology as an educational tool that can bridge the infrastructure gap [3].

Based on data from IDC (International Data Corporation) in 2014, Android holds $84.4 \%$ market share of smartphones worldwide, iphone operating system is the iPhone's operating system in second rank with $11.7 \%$, followed by Windows Phone as the third rank by $2.9 \%$, and Blackberry as the fourth rank with $0.5 \%$ market share. Android has been provided free and paid apps by Android developers making it easier for users. Currently there are many applications provided through the Play Store and users just download and install it into the smartphone.

The Android app developers use Eclipse as the IDE (Integrated Development Environment). According to Zuliana and Padli [18] integrated development environment is a computer program that has some facilities required in software development. Eclipse is a popular IDE among Android developers because Eclipse has the complete Android plug-in available to develop Android apps. In addition, Eclipse gets direct support from Google to become the Android development IDE to create an Android project where the source software directly from its official Google site.

The Indonesian Language Skill course covers four aspects: listening, speaking, reading and writing skills. Listening and speaking skills, are receptive skills, dominated by pre-school students. At school they begin to learn productive skills, namely reading and writing. These four language skills are sometimes called "macro skills". This is different from "micro skills", ie things like grammar, vocabulary, pronunciation and spelling. The four basic skills are related to each other with two parameters: (1) communication means: oral or written and (2) communication directions: receiving or producing messages [2]. In communication, the boundary between spoken and written language is no longer clearly distinguishable [11]. Language skills open up all the 
opportunities that exist in the world [6]. The statement shows that people who have good language skills will be easier to deal with and solve problems in life.

Speech skills have been claimed as the core of language learning. The claim has been reinforced by the assumption that the ability to achieve successful oral speech production is identic to the success of language learning (Kosar \& Bedir, 2014: 12). Student achievement in learning will be demonstrated by how the student receives and reproduces what material he has learned. This can be measured by looking at how he expresses his understanding in terms of speaking ability.

The literature learning resource plays an important role in language learning, but there is little pedagogically appropriate material that can be used in learning [7]. Griffiths's research findings [4] highlight the importance of reading for the development of language skills. The argument that can be put forward to support Griffiths findings is that people with a high reading interest always seek and gain new knowledge. The activity is certainly able to improve the competence of other linguistic. Source of reading in the form of printed version is not as much as presented in the internet. In addition, the printed version reading source requires a special place so it is not easy to be carried around. In contrast, mobile phone media can accommodate a very large number of sources and easy to carry because of its relatively small form.

Based on the explanations described above, this study aims to describe the use of android media in learning and improve the quality of learning Indonesian language skills of PGSD students through the use of android media.

\section{METHOD}

The type of this research is action research. This action research is carried out in a classroom area so that it is called classroom action research. Classroom action research is a practical research intended to fix or improve the quality of learning in the classroom and this corrective action is carried out by carrying out actions to seek answers to the issues raised from daily task activities in the classroom [8]. The classroom action research model used in this study is a self-reflection spiral system developed by Kemmis and Taggart [9] that begins with plans, actions, observations, reflections, and re-planning that form the basis for an eventual problem-solving.

The place of this research is the Study Program PGSD Kebumen FKIP UNS. This research had been conducted for one semester that was in even semester of the academy year of 2016-2017. The subjects of this study are all students of the fourth semester with lecturers and lecturers's associate. The data of the research is in the form of data about the planning, implementation, and evaluation in the learning process of Indonesian Language Skills course.

The data collection tools used in this research are (a) field notes, (b) evaluation in the form of the writing works / articles. In this case, the researcher plays a role as the main instrument that has the ability to select, rate, conclude, and decide the data (Moleong, 1989). Data collection techniques used in this research are in the form of observation techniques and subjective tests which is in the form of composing article. The task of composing articles is for written assessment and speaking in front of the class for oral assessment. Observation technique is carried out during the learning process to find out how the activities of the students in using the mobile phone. This can 
be known through communication through the WhatsApp group and their activities through facebook. The test technique is used to find out how far the mastery of students to the material learned by putting it in the form of talking or writing essays or articles. For the sake of validity of the data this research uses triangulation technique. Data analysis was conducted by qualitative analysis, covering three flow of activities at the same time continuously during and after collecting the data, namely (1) data reduction, (2) display / presentation of data, and (3) conclusion / verification.

Performance indicators are descriptions of clues or signs that are expected to emerge as a form of success in taking action. The results generally targeted as performance indicators in this study are PGSD students have adequate proficiency in Indonesian language in order to be able to create and produce writing works / articles in accordance with the rules of composition as one of the competencies that should be owned by students. They are the determination of the topic and the title of the essay, the composition of effective sentences, the development of paragraphs, the structure of the essay, the selection of words or diction, and the application of spelling and punctuation rules.

Stages of activity in this research uses Kemmis and Mc Taggart [9] model consisting of 4 stages, namely (1) planning / plan, (2) action, (3) observation, and (4) reflection. These stages were carried out continuously and sustainably (spiral) so as to find optimal result. This activity was carried out collaboratively based on the planning that has been prepared. In practice, this action had been done by lecturer of Indonesian Language Skills or researchers. The implementation of the actions which is in accordance with the plan of this study are as follows: (1) learning oral skills (2) learning skills of written language.

\section{RESULTS AND DISCUSSION}

\section{Action I}

Learning language skills are divided into two aspects, namely oral language skills and writing skills. Oral skill includes listening skill and speaking skill. These activities were conducted in the classroom in face-to-face activities. The first step taken was about general explanation of the material to be learned and the techniques undertaken to study the material. The next step was creating WhatsApp group. The WhatsApp Group was chosen with a reason to facilitate communication between lecturers and students as well as between students and other students. The first material to be learned was the essence of oral language skills, namely listening and speaking.

Lecturers provided assignments through WA messages so that students search the material through the internet. In classroom learning, students were divided into groups consisting of five to seven people. The task of seeking material between one group and the other groups is different. However, the duty of each student is to master all material, whether assigned to his or her own group or any other groups. It was intended that the material obtained will be extra materials and more complex.

At the next meeting each group presented their duties. This presentation activity was intended to train and develop speaking and listening skills. Presenter groups develop their speaking skills, while other groups should focus on listening skills in order to understand and respond to what the presenter groups were saying. This is 
consistent with Brownwell's statement that listening is listening, understanding, reminder, interpretation, evaluation, and response [14].

The students' speaking skills were developed through group discussions, both in the internal group and with other groups. This activity was used to develop the courage to speak to convey ideas, ask questions, respond to other people's ideas, refute, and criticize, and also provide advice with logical arguments. On the other hand, in this activity the student must concentrate in order to follow the discussion process. Concentration is needed to understand what other students are saying and to get the same perception with the speaker. The same perception of a topic is important in the discussion process.

From the same theoretical material, such as listening definitions, listening objectives, factors affecting listening success, students find various explanations obtained by searching the internet using google chrome, mini opera, UC browser, or other search engine applications.

From this diverse material, the discussion forum was so intense that the comprehension of the resulting material is more comprehensive and complex. They share information and complement each other.

Beside had been done in the classroom, discussion forums also done outside the classroom with no bound places and time. WhatsApp media overcomes the difference in place and time. The students discussed various problems through the WA group, the lecturers followed and directed to get the conclusions. This forum can also solve the problem of the absence of students or lecturers in the classroom.

\section{Action II}

The second action in this research was the writing language skills, namely reading and writing. Learning material of text reading was presented by lecturer through WA media. Submission of materials was done before classroom. Students must open WA to read and understand the content of the material. Various types of reading were presented through WA. In the lecture class, students discussed material about the structure of writing, diction, grammar, spelling, punctuation, and not less important is also the text content.

Learning reading cannot be separated by writing. Understanding the contents of the text is known from the writings it produces. Group learning was also done in this action. Students read and discussed the types of texts according to their form and purpose, such as narrative, description, exposition, argument, and persuasion. Based on the example given by the lecturers, they were given the task of searching for these types of texts on the internet, then reporting them in front of the class individually.

Furthermore, the development of student writing skill was carried out through assignment. At first they were instructed to read an example of a shared narrative form through WA. Then, they composed a narrative. One of the students was appointed by the lecturer to present his writing work, then the other responded, and so on alternately responded to each other's writing works. Such activities were carried out for other types of articles. They presented and responded to each other. In this way, the creativity of each student developed according to their own potential.

The response given by the students on the writings of other students must be related to linguistic rules, such as grammar, diction, morphology, syntax, and spelling. The quality of student responses was determined by the depth of language knowledge one 
has. The resulting impact was the students can mutually correlate with each other. This is consistent with the findings of Arias \& Sabana, TT: 5 [1] which states that peer correction helps improve their informal writing. Another impact as a result of mutual correction was the development of cooperative attitude, mutual respect for the opinions of others, and tolerance. However, the correction of lecturers on student writing is not neglected. Students may receive corrections from their friends, but lecturer corrections are prioritized, as Sultana [15] in his research on students in Bangladesh. The findings of that research are in line with the conclusions of Ulfah, Fuady, and Wardani [16] stating that the application of peer-correction techniques can improve the quality of learning outcomes of writing scientific papers on students of grade XI SMA N 2 Sukoharjo which is supported by the improvement of scientific writing Seen from the increasing ability of students in writing scientific papers which assessments are based on content aspects, organizational content, vocabulary, language development, and written mechanics.

Writing skills as a last skill in the acquisition of language skills in this act is a blend of three previous language skills: listening, speaking and reading. The task given to students was to read books or articles that exist on the internet then they were instructed to make a response in the form of criticism or reviews.

\section{CONCLUSION}

Based on the research results above can be concluded that (1) android smartphone can be used as a medium of learning Indonesian language skills as a support for face-toface learning in the classroom; learning was done by apps WhatsApp, google chrome, mini opera, UC browser, or other search engines; Group discussions through the WA group can overcome the limitations of space and time; (2) Android smartphone as media can be used to improve the quality of learning Indonesian language skills in PGSD. Interrelated listening, speech, reading, and writing skills can flourish with android media. Knowledge sharing between students and lecturers is effective through listening and speaking activities; reading activities conducted with the help of android smartphone media can increase the knowledge of students in various fields so that support the skills of speaking and writing. In addition, students are able to produce comprehensive writing in the form of responses, essays, and book reviews.

\section{REFFERENCES}

[1] Arias, T.J.R. \& Sabana, U. (TT). Peer Correction Technique. Department of Foreign Language and Culture.

[2] Aydoğan, H. \& Akbarov, A.P.A. 2014. The Four Basic Language Skills, Whole Language \& IntergratedSkill Approach in Mainstream University Classrooms in Turkey. Mediterranean Journal of Social Sciences. Vol 5. No. 9, May 2014. Page 672-681.

[3] Beckwith, L. 2013. Leveraging Mobile Technology to Facilitate Acquisition of English as a Second Language (ESL) in Public Schools Throughout the World. Educational Portal of the Americas Department of Human Development, Educational and Culture. Digital Magazine N 147. Page 1-15.

[4] Griffiths, C. 2004. Studying in English: Language Skills Development. School of Foundation Studies. AIS St Helens, Auckland, New Zealand. Occasional Paper No. 5. October 2004. Page 1-13.

[5] Hardianto, D. 2005. Media Pendidikan sebagai Sarana Pembelajaran yang Efektif. Majalah Ilmiah Pembelajaran 1, Vol. 1. Hal. 95-104. 
[6] Hemingway, A. 2012. Using your language skills. University of Surrey. www.agcas.org.uk/disclaimer.

[7] Hismanoglu, M. 2015. Teaching English Through Literature. Journal of Language and Linguistic Studies. Vol.1, No.1, April 2005. Page 53-66.

[8] Kasbolah, K. 2001. Penelitian Tindakan Kelas. Malang: Penerbit Universitas Negeri Malang.

[9] Kemmis, S. \& Taggart, R.B. 1990. The Action Research Planner. Third Edition. Victoria: Deakin University.

[10] Kosar, G. \& Bedir, H. 2014. Strategies-Based Instruction: A Means of Improving Adult Efl Learners' Speaking Skills. International Journal of Language Academy. Volume 2/3 Autumn, 2014 p. 12-26.

[11] Lotherington, H. 2004. What Four Skills? Redefining Language and Literacy Standards for ELT in the Digital Era. Tesl Canada Jouanaurevue Tesl Du Canada. Vol. 22 No. 1, Winter 2004. Page 6478.

[12] Milles, M.B. \& Huberman, A.M. 1992. Qualitative Data Analysis. Baverly Hills: Sage Publisher.

[13] Moleong, L.J. 1989. Metodologi Penelitian Kualitatif. Bandung: Remaja Karya.

[14] Pyles, A., Donohue, E., \& Gunzelmann. 2004. Effective Listening Skills. Center for Workforce Development, www.newconversations. net; Chapter 8 of Dr. Ford's Workbook.

[15] Sultana, A. 2009. Peer Correction in ESL Classrooms. BRAC University Journal, vol. V1, no. 1, 2009, pp. 11-24.

[16] Ulfah, M., Fuadyu, A., dan Wardani, N.E. 2012. Teknik Peer-Correction untuk Meningkatkan Kualitas Proses dan Hasil Pembelajaran Menulis Karya Ilmiah Siswa Sekolah Menengah Atas. BASASTRA Jurnal Penelitian Bahasa, Sastra, Indonesia dan Pengajarannya. Volume 1 Nomor 3, Desember 2012.

[17] Wirawan, P.W. 2011. Pengembangan Kemampuan E-Learning Berbasis Web ke dalam M-Learning. Jurnal120 Universitas Diponegoro. (Vol. 2. No. 4 Hlm 22-23). http://ejournal.undip.ac.id/index.php/jmasif/ article/view/ 2655 Diunduh pada 9 Juni 2017.

[18] Zuliana dan Padli, I. 2013. Aplikasi Pusat Panggilan Tindakan Kriminal di Kota Medan Berbasis Android. Jurnal. IAIN Sumatera Utara Medan (hlm 2-4). 